\title{
Anxiety and Politics
}

\author{
Franz L. Neumann
}

Abstract: The English version of this article was first published in 1957. The journal tripleC: Communication, Capitalism \& Critique republished it 60 years later in 2017. In this essay, Franz L. Neumann discusses the role of anxiety in politics. The article asks: How does it happen that the masses sell their souls to leaders and follow them blindly? On what does the power of attraction of leaders over masses rest? What are the historical situations in which this identification of leader and masses is successful, and what view of history do the men have who accept leaders? For answering these questions, the author suggests a combination of political economy, Freudian political psychology, and ideology critique. He sees anxiety in the context of alienation. Alienation is analysed as a multidimensional phenomenon consisting of economic, political, social and psychological alienation. Neumann introduces the notions of Caesaristic identification, institutionalised anxiety and persecutory anxiety. The essay shows that fascism remains an actual threat in capitalist societies.

Keywords: Critical theory, Franz L. Neumann, anxiety, politics, authoritarianism, fascism, political psychology, political economy, alienation, ideology critique, Karl Marx, Sigmund Freud

Acknowledgement: The editors of tripleC express their gratitude to the Neumann and Marcuse families for their support in republishing this essay, to Simon \& Schuster for granting us the rights, and to Denise Rose Hansen for her invaluable editorial assistance. Original source: From the book "The Democratic and the Authoritarian State" by Franz Neumann. Copyright $(\subset) 1957$ by the Free Press. Copyright renewed $(1985$ by the Free Press, a division of Macmillan, Inc. Reprinted by permission of Free Press, a Division of Simon \& Schuster, Inc. Originally delivered as a lecture before the Free University of Berlin and published in the series "Recht und Staat," Tübingen,1954. Translated by Professor Peter Gay. This article is published in tripleC without a CC licence.

On January 6, 1941, President Franklin D. Roosevelt proclaimed the Four Freedoms: Freedom of Speech, Freedom of Religion, Freedom from Want, and Freedom from Fear. But with the end of the Second World War anxiety has not disappeared from the world. On the contrary, it has become even greater and more frightful; it has begun to paralyze nations and to make men incapable of free decisions ${ }^{1}$.

Anxiety is, or ought to be, a central problem of the sciences. Anxiety impairs the freedom of decision, indeed it may make such freedom impossible-only a fearless man (or woman, ed.) can decide freely. The discussion of the problem of anxiety should be open to all the disciplines, not reserved to any one of them, for the great concern of science is the analysis and application of the concept of human freedom.

My task today is to discuss the problem of anxiety in politics, a task which is confronted with many obstacles. In contrast to the traditional disciplines, the science of politics has no method of its own-it has, in the last analysis, only a focus, namely the dialectical relation between domination and freedom. In other words the science of politics revolves solely around a problem and uses all kinds of methods to attack this problem. However, with this approach the political scientist runs the danger of dilettantism, a danger which he can avoid only by being conscious of his limitations 
and by giving hearing to authorities from other disciplines. Thus this contribution will often consist merely in a synthesis of the results of research or perhaps in a felicitous hypothesis.

But a second, even greater obstacle consists in the inadequate state of the discussion of anxiety in psychological literature. If I rely extensively on Freud in what follows I do so not because I accept his therapeutic method-of that I understand nothingbut because his theoretical insights seem to me convincing and not refuted up to now.

My lecture will have to take a position on many questions which have not yet been clarified, and it is my hope that it will move other and more competent scholars to analyze the problems I have raised.

\section{Alienation}

1.

In his Letters „Über die ästhetische Erziehung des Menschen,” Schiller has magnificently described man in modern society ${ }^{2}$. "Man portrays himself," he writes, "and what a form is presented in the drama of the modern age? Barrenness here, license there; the two extremes of human decay, and both united in a single period"3. As Rousseau did before him, Schiller indicts civilization itself: "It was culture itself which inflicted this wound on modern humanity" 4 . And this wound was inflicted on man by the division of labor: "Gratification is separated from labor, means from ends, effort from reward. Eternally fettered only to a single little fragment of the whole, man fashions himself only as a fragment [..." $]^{\prime 5}$. His indictment of modern society reaches its climax in the characterization of love: "So jealous is the state for the sole possession of its servants that it would sooner agree (and who could blame it?) to share them with a Venus Cytherea than with a Venus Urania"6. Schiller has, of course, taken the two forms of the goddess of love from Plato's Symposium and thus identifies Venus Cytherea with venal but Urania with genuine love.

What Schiller describes so impressively is what Hegel and Marx were to characterize as alienation ${ }^{7}$. Schiller contrasts the "polypus nature" of the Greek states, "where each individual enjoyed an independent existence and, if necessary, could become a whole" ${ }^{8}$, with modern society which is one of hierarchical division of labor ${ }^{9}$. Modern Society produces a fragmentation not only of social functions but of man himself who, as it were, keeps his different faculties in different pigeonholes-love, labor, leisure, culture-that are somehow held together by an externally operating mechanism that is neither comprehended nor comprehensible. One may-as I do-consider Schiller's (as also Hegel's) analysis of the Greek state as strongly unrealistic and one may, perhaps, even see certain dangers in the glorification of Greece ${ }^{10}$; nevertheless his analysis of modern man, pointing far beyond his age, remains valid and it is perhaps only today that we have become fully conscious of how true Schiller's Letters are.

\section{2.}

In his Theologische Jugendschriften ${ }^{11}$ Hegel developed for the first time the concept of alienation. In his draft, entitled "Love"12, he defined love as the "whole", as "a feeling, but not a single feeling". "In it, life finds itself, as a duplication of its self, and as its unity". But this love is frequently shattered by the resistance of the outside world, the social world of property, a world indeed which man has created through his own labor and knowledge but which has become an alien, a dead world through property. 
Man is alienated from himself. Since we are here not concerned with the Hegelian concept of alienation, we may pass over the development of his concept ${ }^{13}$.

It is equally unnecessary for us here to develop fully Marx's concept of alienation ${ }^{14}$. For Marx it is the commodity that determines human activity, that is, the objects which are supposed to serve man become the tyrant of man. For according to Marx, who thus fully agrees with Schiller, Hegel, and Feuerbach, man is a [universal] being. Man is free if he "recognizes himself in a world he has himself made" 15 . But that does not happen. Since "alienating labor (1) alienates man from nature, (2) alienates him from himself, his own active function, his life's activity, it alienates man from his species" $^{16}$. The separation of labor from the object is thus for him a threefold one: man is alienated from external nature, from himself, and from his fellow-men. The relations of men to one another are reified: personal relations appear as objective relations between things (commodities).

Man, (not only the worker, since the process of alienation affects Society as a whole $)^{17}$ is thus for Marx as for Schiller, Feuerbach and Hegel, a mutilated man.

\section{3.}

But these theories of alienation are not adequate. While the principles developed by Hegel and Marx must not be given up, these theories need supplementation and deepening. Their inadequacy consists in this, that they oppose universal or nearly universal man (of ancient Greece in Schiller and Hegel) to the mutilated man of the modern world ${ }^{18}$. But there is no historical form of society in which men have ever existed as universal beings; for slavery is not compatible with universality. My meaning may, perhaps, become clearer if I distinguish three strata of alienation: The stratum of psychology; that of society; and that of politics.

We can get at the problem of alienation, and thus of anxiety in politics, only if we start with a clean separation of the three strata and concepts, in order later to bring them together again. Neither alienation nor anxiety is to be found only in modern society and only in modern man, although the different structures of society and of the state modify the forms of expression which alienation and anxiety take. The modifications are hard to determine, and I shall not attempt here to undertake a systematic analysis. But I shall try to point up the problem and to make the theory somewhat more concrete by means of (more or less arbitrary) examples.

\section{Alienation and Anxiety}

\section{1.}

Freud's thesis in his Civilization and its Discontents is this: "The goal towards which the pleasure-principle impels us —of becoming happy—is not attainable"19; because for Freud suffering springs from three sources: external nature, which we can never dominate completely, the susceptibility to illness and the mortality of the body, and social institutions ${ }^{20}$.

However, the statement that society prevents happiness, and consequently that every socio-political institution is repressive, does not lead to hostility toward civilization. For the limitation, which is imposed upon the libidinal as well as the destructive instincts, creates conflicts, inescapable conflicts, which are the very motors of progress in history. But conflicts deepen with the progress of civilization, for Freud states that increasing technical progress, which in itself ought to make possible a greater measure of instinct gratification, fails to do so. There arises here a psychological lag 
that grows ever wider-a formulation that I should like to borrow from the "cultural lag" of American sociology.

Thus every society is built upon the renunciation of instinctual gratifications ${ }^{21}$. Freud finds that it is "not easy to understand how it can become possible to withhold satisfaction from an instinct. Nor is it by any means without risk to do so; if the deprivation is not made good economically, one can be certain of producing serious disorders" ${ }^{22}$. To be sure, according to Freud it is conceivable "that a civilized community could consist of pairs of individuals (who love each other) libidinally satisfied in each other, and linked to all the others by work and common interests. If this were so, culture would not need to levy energy from sexuality"23. But the opposite is true and has always been true. For at bottom Freud does not believe in this "conceivable ideal". The differences between the different forms of society-which are decisive for usdo not play a decisive role for him. ${ }^{24}$ The renunciation of instinctual gratification and the cultural tendency toward the limitation of love operate at all levels of society. It is these renunciations and limitations which we characterize as psychological alienation of man, or perhaps even better as alienation of the ego from the dynamics of instinct.

\section{2.}

Still another preparatory step is necessary: we have to establish the logical connection between alienation and anxiety. This is extremely difficult because the discussion of the problem of anxiety has by no means reached the clarity which would snake it possible for an outsider-like myself-to adopt an unambiguous position toward the various opinions ${ }^{25}$. Nevertheless it seems to me that the differences in the conception of the origin of anxiety do not have a decisive significance for my analysis, although they are, of course, highly relevant in other contexts. Freud himself had originally derived anxiety from the repression of libidinous impulses, and thus had seen it as an automatic transformation of instinctual energy ${ }^{26}$. This view he later modified ${ }^{27}$. Others claim, on the other hand, that there is a single inborn faculty for being afraid ${ }^{28}$. Rank, in his famous work ${ }^{29}$, derives anxiety from the trauma of birth. And a number of analysts have tried, more or less successfully, to combine the various theories in many ways $^{30}$.

The following propositions seem to me more or less acceptable.

One must distinguish between true anxiety (Realangst) and neurotic anxiety. The difference is of considerable consequence especially for the understanding of the political importance of anxiety. The first true anxiety-thus appears as a reaction to concrete danger situations ${ }^{31}$; the second-neurotic anxiety-is produced by the ego, in order to avoid in advance even the remotest threat of danger. True anxiety is thus produced through the threat of an external object; neurotic anxiety, which may have a real basis ${ }^{32}$, on the other hand is produced from within, through the ego.

Since anxiety is produced by the ego, the seat of anxiety is in the ego, not in the id-the structure of instincts. But from the analysis of the problem of psychological alienation it follows necessarily that anxiety, feelings of guilt, and the need for selfpunishment are responses to internal threats to basic instinctual demands ${ }^{33}$ so that anxiety exists as a permanent condition. The external dangers which threaten a man meet the inner anxiety ${ }^{34}$ and are thus frequently experienced as even more dangerous than they really are. At the same time, these same external dangers intensify the inner anxiety. The painful tension which is evoked by the combination of inner anxiety and external danger can express itself in either of two forms ${ }^{35}$ : in depressive or in persecutory anxiety. The differentiation is important because it helps us to evaluate the political function of anxiety more correctly. 
In the history of the individual there are certain typical dangers which produce anxiety. For the child the withdrawal of love is of decisive importance. On this point there seems to be no doubt among psychologists ${ }^{36}$. From the numerous phobias we may learn a great deal about the relation between anxiety and the renunciation of instinctual gratification. For inhibitions are a functional restraint of the ego; the ego renounces many activities in order to avoid a conflict with the id and the conscience. We know that the phobic symptoms are a substitute for gratifications of the instincts that have been denied or are unattainable. In other words, the ego creates anxiety through repression.

\section{3.}

If I have correctly reproduced the most important results of analytical theory concerning the origin of anxiety, several important consequences for the analysis of political behavior seem to follow immediately. Anxiety can play very different roles in the life of men; that is, the activation of a state of anxiety through a danger can have a beneficial as well as destructive effect. We may perhaps distinguish three different consequences:

(a) Anxiety can play a warning role, a kind of mentor role, for man. Affective anxiety may allow a presentiment of external dangers. Thus anxiety also contains a protective function. ${ }^{37}$ For it permits man to take precautions in order to ward off the danger.

(b) Anxiety can have a destructive effect, especially when the neurotic element is strongly present; that is, it can make man incapable of collecting himself either to escape the danger or to fight against it; it can paralyze man and degenerate into a panicky anxiety.

(c) Finally, anxiety can have a cathartic effect; ${ }^{38}$ man can be strengthened inwardly when he has successfully avoided a danger or when he has prevailed against it. One may perhaps even say (although I cannot prove this) that the man who has conquered anxiety in coming to terms with a danger, may be more capable of making decisions in freedom than the one who never had to seriously wrestle with a danger. This may be an important qualification of the proposition that anxiety can make free decision impossible.

\section{Anxiety and Identification}

Our analysis of the relation of alienation to anxiety does not yet permit us to understand the political significance of these phenomena, because it is still in the realm of individual psychology ${ }^{39}$. How does it happen that masses sell their souls to leaders and follow them blindly? On what does the power of attraction of leaders over masses rest? What are the historical situations in which this identification of leader and masses is successful, and what view of history do the men have who accept leaders?

1.

Thus the question concerning the essence of the identification of masses and a leader stands in the center of group-psychological analysis. Without it the problem of the integration or collectivization of the individual in a mass cannot be understood. I assume that the history of the theories of group psychology is familiar ${ }^{40}$. The extraordinary difficulty in the comprehension of group-psychological phenomena lies first of ail in our own prejudices; for the experiences of the last decades have instilled in us all 
more or less strong prejudices against the masses, and we associate with "masses" the epithet "mob," a group of men who are capable of every atrocity. In fact the science of group psychology began with this aristocratic prejudice in the work of the Italian Scipio Sighele ${ }^{41}$, and Le Bon's famous book ${ }^{42}$ is completely in this tradition. His theses are familiar. Man in the mass descends; he is, as it were, hypnotized by the leader (operateur) and in this condition is capable of committing acts which he would never commit as an individual. As the slave of unconscious-i.e., for Le Bon, regressive-sentiments, man in the mass is degraded into a barbarian: "Isolated, he may be a cultivated individual; in a crowd, he is a barbarian-that is, a creature acting by instinct. He possesses the spontaneity, the violence, the ferocity, and also the enthusiasm and heroism of primitive beings" ${ }^{43}$. Critics of Le Bon, among them Freud ${ }^{44}$, have pointed out that his theory, which rests on Sighele and Tarde, is inadequate in two aspects: the answer to the question, What holds the masses together? is inadequate, for the existence of a "racial soul" 45 is unproved. In addition, in Le Bon the decisive problem-the role of the leader-hypnotist-remains unclarified ${ }^{46}$. As is frequently true in social-psychological studies, the descriptions of psychological states are adequate, the theoretical analyses, the answers to "Why?," are inadequate ${ }^{47}$.

\section{2.}

From the outset, Freud sees the problem in the way in which we have put it, namely, as that of the identification of masses with a leader-an identification which becomes of decisive significance particularly in an anxiety situation. And he sees in the libido the cement which holds leader and masses together, whereby, as is known, the concept of libido is to be taken in a very broad sense, to include the instinctual activities which "in relations between the sexes [...] force their way toward sexual union," as well as those which "in other circumstances [...] are diverted from this aim or are prevented from reaching it, though always preserving enough of their original nature to keep their identity recognizable (as in such features as the longings for proximity, and self-sacrifice)" ${ }^{\prime 48}$.

The cement which holds the mass together and ties them to the leader is thus a sum of instincts that are inhibited in their aims ${ }^{49}$. In this manner, I believe, the logical connection between alienation and mass behavior has been established.

Since the identification of masses with the leader is an alienation of the individual member, identification always constitutes a regression, and a twofold one. On the one hand, the history of man is the history of his emergence from the primal horde and of his progressive individualization; thus the identification with a leader in a mass is a kind of historical regression ${ }^{50}$. This identification is also a "substitute for a libidinal object tie" ${ }^{\prime \prime}$, thus a psychological regression, a damaging of the ego, perhaps even the loss of the ego.

\section{3.}

But this judgment is valid only for the libido-charged, i.e., affective, identification of an individual in a mass with a leader; and not as a matter of course (and perhaps not at all) for that of lovers and of small groups. Non-affective identification too, cannot be simply considered as regressive. For identification with organizations (church, army) is not always libidinally charged. MacDougall's emphasis on the significance of organization must therefore be taken seriously.

It is thus necessary to make distinctions. There are non-affective identifications, in which coercion or common material interests play an essential role, either in bureau- 
cratic-hierarchic, or in co-operative form. It seems to me to be incorrect, above all for recent history, to see in the identification of the soldier with the army, i.e., in the loyalty to an organization, an actual identification of the soldier with the commander-inchief. Surely there are examples of this: Alexander, Hannibal, Caesar, Wallenstein, Napoleon. But the commander-in-chief of the $20^{\text {th }}$ century is much more the technician of war than the leader of men, and the libidinal tie of the soldier is, if I may coin the phrase, essentially cooperative, namely, with the smallest group of comrades with whom he shares dangers.

Thus I would like to establish two fundamental types of identification: a libidocharged (affective) and a libido-free (non-affective); and maintain generally (as it follows from MacDougall's psychology) that the non-affective identification with an organization is less regressive than the affective identification with a leader. Nonaffective loyalty is transferable ${ }^{52}$; personal loyalty, on the other hand, is not. The former always contains strong rationalist elements, elements of calculability between organization and individual, and thus prevents the total extinction of the ego ${ }^{53}$.

But I believe that one must also distinguish two types within affective identification. One may call them co-operative and caesaristic. It is conceivable (and it has probably happened in short periods in history) that many equals identify themselves cooperatively with one another in such a manner that their egos are merged in the collective ego ${ }^{54}$. But this co-operative form is rare, limited to short periods or in any case operative only for small groups. The decisive affective identification is that of masses with leaders. It is - as I have said-the most regressive form, for it is built upon a nearly total ego-shrinkage. It is the form which is of decisive significance for us. We call it caesaristic identification ${ }^{55}$.

\section{Caesaristic Identification and False Concreteness: The Conspiracy Theory in History}

Caesaristic identifications may play a role in history when the situation of masses is objectively endangered, when the masses are incapable of understanding the historical process, and when the anxiety activated by the danger becomes neurotic persecutory (aggressive) anxiety through manipulation.

From this follows, first of all, that not every situation dangerous to $s$ masses must lead to a caesaristic movement; it follows, further, that not every mass movement is based on anxiety, and thus not every mass movement need be caesaristic.

Thus it is a question of determining the historical conditions in which a regressive mass movement under a Caesar tries to win political power.

\section{1.}

However, before we describe these historical situations, I may perhaps point to a clue which will frequently permit us an early diagnosis of the regressive character of such a mass movement. This clue is the view of history which the masses and the leaders employ. It may be called the conspiracy theory of history, a theory of history characterized by a false concreteness. The connection between caesarism and this view of history is quite evident. Just as the masses-hope-for-their deliverance from distress through absolute oneness with a person, so they ascribe their distress to certain persons, who have brought this distress into the world through a conspiracy. The historical process is personified in this manner. Hatred, resentment, dread, created by great upheavals, are concentrated on certain persons who are denounced as devilish conspirators. Nothing would be more incorrect than to characterize the enemies as scapegoats (as often happens in the literature), for they appear as genuine 
enemies whom one must extirpate and not as substitutes whom one only needs to send into the wilderness. It is a false concreteness and therefore an especially dangerous view of history. Indeed, the danger consists in the fact that this view of history is never completely false, but always contains a kernel of truth and, indeed, must contain it, if it is to have a convincing effect. The truer it is, one might say, the less regressive the movement; the falser, the more regressive.

It is my thesis that wherever affective (i.e., caesaristic) leader-identifications occur in politics, masses and leader have this view of history: that the distress which has befallen the masses has been brought about exclusively by a conspiracy of certain persons or groups against the people.

With this view of history true anxiety, which had been produced by war, want, hunger, anarchy, is to be transformed into neurotic anxiety and is to be overcome by means of identification with the leader-demagogue through total ego-renunciation, to the advantage of the leader and his clique, whose true interests do not necessarily have to Correspond to those of the masses.

Of course, I cannot provide conclusive proof, but I believe that by pointing to certain historical events I can make clear the connection between this view of history and caesarism.

\section{2.}

An interesting affective identification of leader and masses is the relation of Cola di Rienzo to the Roman people ${ }^{56}$. I assume that his story is familiar-the rise of the hack lawyer, son of a Roman innkeeper and a washerwoman, to Tribune of the Rosman people and dictator of Rome, his expulsion and return with the aid of the Church, and his assassination by the Colonna family in the year 1354. The view of history of Cola and of the Roman people was quite simple: Rome has been ruined by feudal lords; their destruction will permit Rome to rise again to its ancient greatness. This is how Petrarca formulates it in his famous letter of congratulation to Cola: "These barons in whose defense you (the Romans) have so often shed your blood, whom you have nourished with your own substance [...] these barons have judged you unworthy of liberty. They have gathered the mangled remnants of the state in the caverns and abominable retreats of bandits [...]. They have been restrained neither by pity for their unhappy country, nor by love for it [...]. Do not suffer any of the rapacious wolves whom you have driven from the fold to rush again into your midst. Even now they are prowling restlessly around, endeavoring through fraud and deceit [...] to regain an entrance to the city whence they were Violently expelled" ${ }^{\prime 7}$. It cannot be denied that the feudal lords, above all the Colonna and Orsini, had pursued a criminal policy. Without this element of truth Cola's propaganda and policy would never have been successful. But fundamentally this was a false concreteness-for oven if he had succeeded in liquidating the barons, what would have been decisively improved in Rome? The historical facts - the residence of the Papal Court in Avignon; the economic decay of Rome; the regrouping of class relations through the rise of the bourgeois cavalerotti-all that Cola could not change. It can hardly be doubted that anxiety, even purely physical fear of the arbitrariness of the barons, drove the people to Cola. Cola succeeded in strengthening this anxiety by extremely skillful propaganda and achieved victory. But the leader himself must feel no anxiety or at least must not show it ${ }^{58}$. He must stand above the masses. But in this Cola was deficient. In all other matters his relation corresponded exactly to that of the libido-charged identification leader-masses, and it is regrettable that time does not permit me to describe and analyze his propaganda themes, his ceremonial, and his ritual. It was Cola's funda- 
mental mistake that he was not enough of a Caesar. To be sure, he publicly humiliated the barons, but he did not liquidate them-whether out of cowardice, decency, or tactical considerations. But the masses of Rome expected that he would act in accordance with their view of history. He did not do this. Thus he had to fall.

I have mentioned Cola di Rienzo because it is a marginal case in which it is doubtful whether we are dealing with a regressive or a progressive movement, that is, a movement which really has the realization of the freedom of man as its goal.

\section{3.}

The eight French religious wars of the $16^{\text {th }}$ century furnish excellent material for the illumination of the character of caesaristic as well as organizational identifications. All three parties-Huggenots, Catholics, and Politiques-were faced with grave problems: the disintegration of the old society through silver inflation, loss of wealth on the one hand, enrichment on the other, the beginnings of radical changes in class relations and the dissolution of the absolute monarchy after the death of Francis I. It is against this background that the religious wars must be understood. Their course is doubtless familiar to you.

Catholics and Protestants alike saw the problem of France only as a religious problem, and therefore ascribed the distress of France exclusively to their religious opponents, conjectured (partly justifiably) that these opponents represented a great and sinister conspiracy, developed or employed theories of caesaristic identification, and consistently proceeded to extirpate the opponent wherever opportunity offered.

The Huguenot pamphleteer Francois Hotman in his Tiger $^{59}$ saw in the Cardinal Guise "a detestable monster," whose aim it was to ruin France, to assassinate the King, and to conspire with the aid of the women near the King and the High Constable of France against "the crown of France, the goods of widows and orphans, the blood of the poor and innocent." Calvin's theory of the secular redeemer sent by God to overthrow tyrants ${ }^{60}$,-in the 17 th century the basis of Cromwell's leadershipbecame the Protestant theory of Caesarism ${ }^{61}$. The Catholics-with a longer tradition of tyrannicide-developed a pseudo-democratic theory of identification, above all in the writings of the Leaguist preachers and Jesuits ${ }^{62}$. In these inflammatory pamphlets whose demagogy even surpasses that of the Huguenots, the theory of democracy is fitted out with theocratic traits, the masses of the people are integrated through the social contract, in order to be identified with Henry of Guise with the aid of the theocratic element, whoever takes the trouble to study the eighth religious war (the War of the 3 Henrys) and the Parisian uprising, will find there all the elements which I consider decisive: appeal to anxiety, personification of evils, first with Henry III, then with Henry of Navarre, identification of the masses with Henry of Guise.

Both positions, the Catholic and the Huguenot, are similarly regressive, while that of the Politiques, which Henry IV was later to convert into action, is incomparably more progressive. Indeed, the great merit of the chief representative of the party of the Politiques, Jean Bodin, consists in this: he saw the economic problems of France clearly ${ }^{63}$; he understood the false concreteness of the view of history of both parties. If he championed absolute monarchy-that is, the identification of the people with the monarch-he did so because the monarch was to place himself above the religions that were fighting each other ${ }^{64}$ and to ally himself with the households ${ }^{65}$ of the third estate in order to save France. Despite the absolute submission to the prince which is demanded of the people, this identification contains the two rational elements which I mentioned before: loyalty becomes transferable, i.e., the office is separated from the officeholder; and the relation between citizen and state becomes rational. 
Thus Bodin has a certain justification in calling his theory a theory of the constitutional state (droit gouvernement) ${ }^{66}$ despite his absolutism. I believe that the French religious wars of the 16th century make my thesis a little clearer: that the non-affective identification with an institution (state) is less regressive than identification with a leader.

\section{4.}

Naturally I cannot here discuss all similar situations. The religious struggles of the 16 th and 17 th centuries are full of such historical constructions.

One need only read, for example, the terrible Calvinist fanatic John Knox in his famous First Blast of the Trumpet against the Monstrous Regiment of Women and we will find there: "We see our countrie set furthe for a pray to foreine nations, we heare the blood of our brethren, the membres of Christ lesus most cruelly to be shed, and the monstruous empire of a cruell woman [...] we knowe to be the onlie occasion of all these miseries" ${ }^{\prime \prime 7}$. The rule of the Catholic Catherine de Medici, of Marie of Lorraine (the predecessor of Mary Stuart) and of Mary Tudor appears here not only as a violation of divine commandment (because God has subjected women to men) but as a genuine conspiracy against the true religion. Unfortunately John Knox had the ill luck of seeing Protestantism restored in England by a woman and he apologized to Elizabeth in a Second Blast ${ }^{68}$ for his first attack.

\section{5.}

Instead of continuing with this survey, it may perhaps be more useful to discuss five fundamental models of conspiracy theories, all of which show this sequence: intensification of anxiety through manipulation, identification, false concreteness. They are
(a) the Jesuit conspiracy
(b) the Freemason conspiracy
(c) the Communist conspiracy
(d) the Capitalist conspiracy
(e) the Jewish conspiracy.

\section{6.}

The Jesuit order ${ }^{69}$ is indeed defined by many as a conspiracy, and the Monita Secreta of $1614^{70}$, composed by a Polish ex-Jesuit, fulfill the need for a secret plan of operations with the help of which one can hold the order responsible for every crime and every misfortune and can stir up the masses. This has always been relatively simple in times of crisis. St. Bartholomew's Night, the assassination of Henry III by Jacques Clément, the attempt on the life of Henry IV by Barrière and Chastel as well as his assassination by Ravaignac, the English Gunpowder plot of 1605, the outbreak of the Thirty Years' War, to say nothing of innumerable less important crimes and misfortunes, were ascribed to the Jesuits. That these tales should have been believed, is naturally connected with the significance of false concreteness in politics. There is some truth in many of these accusations. It is precisely in this element of truth that the danger of these views of history lies.

\section{7.}

The denunciation of the freemasons is a similar matter. Thus the English believed the Jacobite conspiracies to be the work of freemasons; the French Revolution was as- 
cribed to a mysterious group of Bavarian Illuminati ${ }^{71}$, and this view of history again is closely connected with the anti-Jesuit one, since the Bavarian Illuminati had been founded by Adam Weishaupt in 1776, in order to combat the influence of the Jesuits $^{72}$. Again these assertions have some truth in them. Most of the Encyclopedists were freemasons and more than half of the members of the Estates General belonged to freemasonic lodges. But in this audience surely no detailed discussion is needed to show that the conspiracy theory represents a blurring of history ${ }^{73}$.

\section{8.}

The theory of the Communist conspiracy follows the same model and serves the same purposes. Thus the Russian October Revolution is explained solely as a Blanquist conspiracy ${ }^{74}$, embodied in Trotsky's military revolutionary committee; the German Revolution of 1918 is laid to the charge of the devilish Lenin; the seizure of power by the Bolsheviks in the satellite states is traced back to sinister conspiracies in the Kremlin, and generally the relation of Bolshevism to the world is equated with that of a conspiracy of a small group against the welfare of humanity. Again this is partly true. The October Revolution was a conspiracy-but in a definite historical situation and with an ideology. The Bolsheviks would gladly have manipulated the German Revolution of 1918-but they had neither the strength nor the intelligence to do it, nor could they, even if cleverer, have prevailed in the concrete situation. The Communists in the satellite States naturally conspired-but they could come to power only because the Red Army stood behind them and because the objective situation favored them. No conspiracy, no matter how clever, would have been of any use and was of any use in Western Europe. Nevertheless, the conspiracy theory is believed not only by the masses, but even by serious writers who, strongly under the influence of Pareto's simplistic antithesis between elite and masses, generally tend to see in politics nothing but the manipulation of the masses by elites, and for whom psychology and political science are nothing but techniques of manipulation. The purpose of the theory is clear: potential anxiety-whose concrete significance still needs to be clarified-is actualized by reference to the devilish conspirators: family, property, morality, religion are threatened by the conspiracy. Anxiety easily becomes neurotic persecutory anxiety, which in turn can, under certain circumstances, lead to a totalitarian mass movement.

9.

We could cite a great many more cases in which history was viewed with false concreteness. Especially American history is full of examples of such movements. There is, for instance, the Know-Nothing Party of 1854-55 with its hatred of the Irish Catholics and the German immigrants. It originated in the secret "Order of the StarSpangled-Banner" which was founded by native-born Protestants; they mistreated Catholics and when asked about the Order they would answer, "I know nothing".

The Ku Klux Klan is better known. Fear of status loss on the part of the whites, especially of the poor whites, vis-à-vis the Negroes and fear of the Pope and the Catholics were the basic factors which made this secret society into a terroristic organization, from its foundation in 1867 to the present day.

The Populist Party (1892) on the other hand, was born out of an agrarian depression, as a protest against the rule of the railway-, industrial-, and credit-monopolies, and agains the gold standard. One of its leaders developed a genuine theory of conspiracy: "According to my views of the subject the conspiracy which seems to have been formed here and in Europe to destroy ... from three-sevenths to one-half of the metal- 
lic money of the world, is the most gigantic crime of this or any other age." (Quoted in S. E. Morrison and H. S. Commager, The Growth of the American Republic, [1940] Vol. II, p. 245).

\section{0.}

In similar fashion Bolshevism operates with the theory of capitalist encirclement, in which the capitalists as a rule are personified by Wall Street. Now again there can be no doubt that there was a policy of encirclement against Bolshevist Russia at the beginning of the revolution; but it would be fatal to believe that the terror was the consequence of the policy of intervention and of the cold war. Possibly the policy of encirclement strengthened the terror, just as the wars of intervention during the French Revolution gave Robespierre's Terror a new impetus. ${ }^{75}$ But the terror as a normal method of politics against the class opponent is contained in the Leninist definition of the dictatorship of the proletariat; it was then extended to the party and finally to the supposedly classless society, without a visible connection with the intensity of the capitalist policy of encirclement. But the Bolshevist view of history, steadily activating anxiety, made possible identification with the leader Stalin and thus underpinned his caesarist dictatorship.

\section{1.}

The most important type - if only because of its immense political influence-is the theory of the conspiracy of the Jews according to the Protocols of the Elders of Zion. ${ }^{76}$ These contain the secret plans of Jewish leaders, supposedly formulated in the year 1897, for achieving Jewish world domination by force, terror, corruption, the disintegrating influence of liberalism, freemasonry, etc. This world domination was to be a mock-democracy, through which the Jewish leaders were to operate. That the Protocols are a forgery, prepared by Czarist Russians, was definitively established by the Bern trial of $1934-35^{77}$. It is equally beyond question that they are essentially a plagiarism of the work by Maurice Joly directed against Napoleon III, Dialogue aux Enfers entre Machiavel et Montesquieu ${ }^{78}$.

But if the Protocols represent a forgery, and if the plans for a Jewish world conspiracy belong in the realms of mythology, where then does that kernel of truth lie which according to my view is necessary to make possible the influence which antisemitism and the Protocols have had $?^{79}$ I shall confine my analysis to Germany, but the German situation can be understood only when one becomes aware of the fact that in Germany before 1933 spontaneous antisemitism was extremely weak. As early as 1942 I wrote, in opposition to an almost unanimous opinion: "The writer's personal conviction, paradoxical as it may seem, that the German people are the least anti-Semitic of all ${ }^{80}$. I still hold to this view today; for it is precisely the weakness of spontaneous antisemitism in Germany which explains the concentration of National Socialism on it as the decisive political weapon.

The element of truth (if one may call it that) is first of all a religious one; the catechistic representation of the crucifixion and with is the blood guilt of the Jews. But this is a thoroughly ambivalent element: for it is precisely the crucifixion of Christ which makes possible the salvation of Christians (and all men); and the spiritually Semitic origin of Christianity is acknowledged by the Church ${ }^{81}$. While thus the historicalreligious defamation of the Jews forms the basis without which antisemitism could hardly be activated, the catechistic representation of the crucifixion is not sufficient by itself. The existence of a total antisemitism can perhaps be better understood if we start from the Policy of National Socialism and seek to understand the role of anti- 
semitism within the political system. I can sketch the problem only in its broadest outlines $^{82}$. Germany of 1930-33 was the land of alienations and anxiety ${ }^{83}$. The facts are familiar: defeat, a tame, unfinished revolution, inflation, depression, non-identification with the existing political parties, non-functioning of the political system-all these are symptoms of moral, social, and political homelessness. The inability to understand why man should be so hard pressed stimulated anxiety which was made into nearly neurotic anxiety by the National Socialist policy of terror and its propaganda of antisemitism. The goal of National Socialism was clear: the welding together of the people with the charismatic leader, for the purpose of the conquest of Europe and perhaps of the world, and the creation of a racial hegemony of the Germans over all other peoples.

But how was the people to be integrated, despite all cleavages of class, party, religion? Only through hatred of an enemy. ${ }^{84}$ But how could one settle on the enemy? It could not be Bolshevism, because it was too strong; the Catholic Church could not be so designated because it was needed politically and loyalties to it were anchored too securely. The Jews remained. They appeared in the public consciousness as powerful, but were in reality weak. They were relative strangers, and at the same time the concrete symbols of a so-called parasitical capitalism, through their position in commerce and finance; they incarnated a supposedly decadent morality through their avant garde position in art and literature; they seemed to be the successful competitors sexually and professionally. With all this the thesis of the Jewish conspiracy had the element of truth necessary to permit this view of history to become a frightful weapon. It would be mistaken to want to construe a connection between the socio-economic status of a person and his antisemitism; that is, to claim that the academically educated person is more immune than the uneducated, or the poorly paid more immune than the better paid. What is correct ${ }^{85}$, however, is that there exists a connection between loss of social status and antisemitism. The fear of social degradation thus creates for itself "a target for the discharge of the resentments arising from damaged self-esteem" ${ }^{\text {. }}$.

This leads us to the analysis of the historical situations in which anxiety grips the masses.

\section{Situations of Collective Anxiety, Identification, Guilt}

I can treat these matters only in the form of theses because I deal with them in detail elsewhere $^{87}$. We have distinguished three strata of alienation. The psychological stratum remains no matter what social institutions man lives in. It creates potential anxiety which man in the mass attempts to overcome through ego-surrender. This affective identification with a leader is facilitated by the notion of false concreteness, the theory of conspiracy.

But so far we have not yet said when such regressive mass movements are activated; that is, when potential anxiety can be activated in such a manner that it can become a cruel weapon in the hands of irresponsible leaders.

In order to get at this problem we must take into account the two other strata of alienations: the social and political.

1.

Alienation of labor: it is the separation of labor from the product of labor through hierarchal division of labor which characterizes modern industrial society. Probably no one doubts that the division of labor as well as the hierarchical organization of labor have shown a steady rise since the industrial revolution of the 18th century. German 
romantic psychology of labor calls this the "de-spiritualization of labor" (Entseelung der Arbeit). This concept as well as the various remedies are dangerous-for they cover up the inevitability of this process of alienation which must be admitted, understood, and accepted. If this does not happen, if one refuses to take account of the inevitability of the division of labor and of the hierarchical ordering of the process of labor and attempts to "spiritualize" labor instead of restricting it to a minimum, then social anxiety is deepened. The attitude of the so-called "new-middle class" (salaried employees) can be understood from this process ${ }^{88}$.

While the so-called new middle class does labor which-to remain with the language of German psychology of labor-is "more de-spiritualized["] than that of the industrial worker, and although his average income probably lies below that of the industrial worker, he yet holds fast to his middle class ideology and customs. Thus he refuses to take account of the inevitability of the process and-as in Germany before 1933-becomes the social stratum most susceptible to Caesarism.

\section{2.}

In a society which is constituted by competition, the competitor is supposed to be rewarded for his effort when he is competent; that is, when he exerts himself, is intelligent, and accepts risks. There is little doubt that the principle of competition dominates not only the economy but all social relations. Karen Horney, a representative of Freudian revisionism ${ }^{89}$, claims that the destructive character of competition creates great anxiety in neurotic persons. Now this is not convincing when genuine competition really prevails, that is, competition in which relatively equally strong persons fight with fair methods; that is, the kind of competition which Adam Smith defines in his Theory of Moral Sentiments as follows: "One individual must never prefer himself so much even to any other individual as to hurt or injure that other in order to benefit himself, though the benefit of the one should be much greater than the hurt or injury to the other" may run as hard as he can and strain every nerve and every muscle in order to outstrip all his competitors. But if he jostle or throw down any of them, the indulgence of the spectator is entirely at an end. It is in violation of fair play, which they cannot admit of"1. I cannot here undertake a social analysis to show that this ethically circumscribed competition does not exist and perhaps never has existed, that in reality a monopolist struggle hides behind it, that, in other words, the efforts of the individual, his intelligence, his vision, his readiness to take risks, are easily shattered by the constellations of power ${ }^{92}$.

Behind the mask of competition, which must not necessarily have destructive effects if it rationally organizes society, there hide in fact relations of dependence. To be successful in present-day society, it is much more important to stand in well with the powerful than to preserve oneself through one's own strength. Modern man knows this. It is precisely the impotence of the individual who has to accommodate himself to the technological apparatus which is destructive and anxiety-creating ${ }^{93}$.

But even where genuine competition is effective, no effort will help if crises ruin the merchant. The inability to understand the process of crises, and the frequent need to ascribe blame for them to sinister powers, is an additional factor in the destruction of ego. This psychological process operated in the so-called "old middle class" of Germany before 1933. But-to repeat-it is hard to see why fair competition must have destructive functions ${ }^{94}$. 
3.

In every society that is composed of antagonistic groups there is an ascent and descent of groups. It is my contention that persecutory anxiety-but one that, as we said above, has a real basis-is produced when a group is threatened in its prestige, income, or even its existence: i.e., when it declines and does not understand the historical process or is prevented from understanding it. The examples are too numerous to be possibly mentioned here. German National Socialism and Italian Fascism are classical examples.

But not only social classes resist their degradation by means of such mass movements; religious and racial conflicts, too, frequently produce similar phenomena. The conflict between Negroes and whites in the southern states of the United States, the contemporary struggle of the South African government against the natives, take place in accord with the following scheme: the anxiety of a dominant white minority that it will be degraded through the economic and political rise of Negroes is used in propagandist fashion for the creation of affective mass movements, which frequently take on a fascist character.

\section{4.}

Social alienation, i.e., the fear of social degradation, is not adequate by itself. The elements of political alienation must be added. Since I devote a separate essay to this phenomenon, I shall only point out briefly what I have in mind. As a rule one is satisfied (above all, in the American literature) with defining abstention from voting at elections as political apathy ${ }^{95}$. But I have pointed out elsewhere that the word "apathy" describes three different political reactions: first, the lack of interest in politics, say the opinion that politics is not the business of the citizen because it is after all only a struggle between small cliques and that therefore fundamentally nothing ever changes; then, the Epicurean attitude toward politics, the view that politics and state only have to supply the element of order within which man devotes himself to his perfection, so that forms of state and of government appear as secondary matters; and finally, as the third reaction, the conscious rejection of the whole political system which expresses itself as apathy because the individual sees no possibility of changing anything in the system through his efforts. Political life can, for example, be exhausted in the competition of political parties which are purely machines without mass participation, but which monopolize politics to such an extent that a new party cannot make its way within the valid rules of the game. This third form of apathy forms the core of what I characterize as political alienation. Usually this apathy, if it operates within social alienation, leads to the partial paralysis of the state and opens the way to a caesarist movement which, scorning the rules of the game, utilizes the inability of the citizen to make individual decisions and compensates for the loss of ego with identification with a Caesar.

\section{5.}

The caesaristic movement is compelled not only to activate but to institutionalize anxiety. The institutionalization of anxiety is necessary because the caesaristic movement can never endure a long wait for power. This is precisely what follows from its affective basis. While the non-affective-mass organization, such as a normal political party, can exist for a long time without disintegrating, the Caesarist movement must hurry precisely because of the instability of the cement that holds it together: the libido charged affectivity. After it has come to power it faces the need of institutionalizing 
anxiety as a means of preventing the extinction of its affective base by its bureaucratic structure.

The techniques are familiar: propaganda and terror, i.e., the incalculability of sanctions. I do not need to discuss this here. Montesquieu, building on [Aristotle] and Machiavelli, distinguished between three constitutional and one tyrannical governmental and social system. According to him, monarchy rests on the honor of the monarch; aristocracy, on the moderation of the aristocrats; democracy, on virtue (i.e., with him, patriotism); but tyranny, on fear ${ }^{96}$. It must, however, not be overlookedand our introductory remarks about alienation and anxiety had no other meaningthat every political system is based on anxiety. But there is more than a quantitative difference between the anxiety which is institutionalized in a totally repressive system and that which is the basis of a halfway liberal one. These are qualitatively different states of affairs. One may perhaps say that the totally repressive system institutionalizes depressive and persecutory anxiety, the halfway liberal system, true anxiety ${ }^{97}$.

Once the connection between anxiety and guilt is seen, it will at once become obvious that these are different states of affairs.

In his Peloponnesian War, Thucydides reports the following about Sparta: "Indeed fear of their [the Helots'] numbers and obstinacy even persuaded the Lacedaemonians to the action which I shall now relate [...]. The Helots were invited by a proclamation to pick out those of their number who claimed to have most distinguished themselves against the enemy, in order that they might receive their freedom; the object being to test them, as it was thought that the first to claim their freedom would be the most high-spirited and the most apt to rebel. As many as two thousand were selected accordingly, who crowned themselves and went round the temples, rejoicing in their new free. dom. The Spartans, however, soon afterwards did away with them, and no one ever knew how each of them perished" ${ }^{\prime 28}$.

With his customary psychological penetration this greatest of all historians saw clearly the connection of anxiety and collective guilt. And then we read Plutarch's description of the terrible Cryptia ${ }^{99}$, the Spartan secret police: "By this ordinance, the magistrates [i.e., the Ephors] despatched privately some of the ablest of the young men into the country, from time to time, armed only with their daggers, and taking a little necessary provision with them; in the daytime, they hid themselves in out-of-theway places, and there lay close, but in the night issued out into the highways and killed all the helots they could light upon"100. Here is a striking example of what we have in mind ${ }^{101}$.

Who does not here think of Dostoyevsky's The Possessed, when Stavrogin gives the following piece of advice: "All that business of titles and sentimentalism is a very good cement, but there is something better; persuade four members of the circle to do for a fifth on the pretence that he is a traitor, and you'll tie them all together with the blood they've shed as though it were a knot. They'll be your slaves, they won't dare to rebel or call you to account. Ha ha ha!"102 This famous passage in Dostoyevsky is important not only because it verifies our psychological theory, but also because it shows at the same time that the leader activates anxiety through guilt for his own advantage, not for the sake of the led.

I do not wish here to discuss the psychological theory concerning the relation of anxiety and guilt. According to Freud ${ }^{103}$ man's feeling of guilt stems from the Oedipus complex. It is this aggression that the child represses and thus effects an unconscious feeling of guilt. The feeling of guilt is the superego, man's conscience. ${ }^{104}$ But that is precisely why the intensification of the unconscious feeling of guilt permits man to become a criminal $^{105}$. 
If one examines the Spartan example, Stavrogin's advice, the Fehme-murders, and the collective crimes of the SS, one may perhaps undertake the following psychological analysis:

There are anxiety and an unconscious feeling of guilt. It is the task of the leader, by creating neurotic anxiety, to tie the led so closely to the leader that they would perish without identification with him. Then the leader orders the commission of crimes; but these are, in accord with the morality that prevails in the group-with the Lacedaemonians, the Nihilists, the SS-no crimes, but fundamentally moral acts. But the conscience - the superego ${ }^{106}$ _protests against the morality of the crimes, for the old moral convictions cannot simply be extirpated. The feeling of guilt is thus repressed and makes anxiety a nearly panicky one, which can be overcome only through unconditional Surrender to the leader and compels the commission of new crimes ${ }^{107}$.

This is how I see the connection between anxiety and guilt in a totally repressive society. Hence this anxiety is qualitatively different from the anxiety that is the basis of every political system.

\section{Summary}

It is time to summarize the results of my analysis:

1. Psychological alienation-the alienation of the ego from the instinctual structure, or the renunciation of instinctual gratifications-is inherent in every historical society. It grows with the growth of modern industrial Society, and produces anxiety. Anxiety can be protective, destructive, or cathartic.

2. Neurotic, persecutory anxiety can lead to ego-surrender in the mass through affective identification with a leader. This caesaristic identification is always regressive, historically and psychologically.

3. An important clue for the regressive character is the notion of false concreteness, the conspiracy theory of history. Its peculiar danger lies in the kernel of truth that is contained in this view of history.

4. The intensification of anxiety into persecutory anxiety is successful when a group (class, religion, race) is threatened by loss of status, without understanding the process which leads to its degradation.

5. Generally, this leads to political alienation, i.e., the conscious rejection of the rules of the game of a political system.

6 . The regressive mass movement, once it has come to power must, in order to maintain the leader-identification, institutionalize anxiety. The three methods are: terror, propaganda, and, for the followers of the leader, the crime committed in common.

It is my contention that the world has become more susceptible to the growth of regressive mass movements. Perhaps not so much in Germany, because the aftereffects of historical experience still work rather strongly, despite all attempts to repress the memory of National Socialism.

You will ask me, What can be done to prevent anxiety-which cannot be eliminated-from becoming neurotic-destructive? Can the state accomplish this? Schillerand with this we return to our point of departure-denies this in his Seventh Letter. He asks and replies: "Should we expect this effect from the state? That is impossible, since the state, as at present constituted, has caused the evil, and the ideal state of reason cannot be the foundation of this improved humanity but must itself be founded thereon"108.

As educators we may thus perhaps say that education deserves the first rank. But Schiller replies to this in the Ninth Letter with the question, "But are we not proceed- 
ing in a circle? Theoretical culture is supposed to induce the practical, and yet the latter is to be the condition of the former? All political improvements should result from education of character-but how can the character ennoble itself under the influence of a barbarous civil polity?"109

Surely there are also other individual solutions-such as love. But it is, after all, accidental whether or not one experiences it, and the risk can be enormous with loss of object. ${ }^{110}$

Hence there remains for us as citizens of the university and of the state the dual offensive on anxiety and for liberty: that of education and that of politics.

Politics, again, should be a dual thing for us: the penetration of the subject matter of our academic discipline with the problems of politics-naturally not day-to-day politics-and the taking of positions on political questions. If we are serious about the humanization of politics; if we wish to prevent a demagogue from using anxiety and apathy, then we-as teachers and students-must not be silent, we must suppress our arrogance, inertia, and our revulsion from the alleged dirt of day-to-day politics. We must speak and write. Idealism, as it is expressed so nobly in Schiller's Letters, must not be for us only a beautiful facade, it must not once more become that notorious form of idealism which in the past disguised the most reactionary and antilibertarian aims.

Only through our own responsible educational and political activity can the words of idealism become history.

\section{About the Author}

\section{Franz L. Neumann}

Franz Leopold Neumann (1900-1954) was a political theorist associated with the Frankfurt School. He obtained a doctoral degree in legal studies at the University of Frankfurt with the dissertation „Rechtsphilosophische Einleitung zu einer Abhandlung über das Verhältnis von Staat und Strafe" (A Legal-Philosophical Introduction to A Treatise on the Relationship between the State and Punishment). Neumann became the German Social Democratic Party's (SPD) main legal advisor at a time when the Nazis and Hitler gained strength in Germany. At the time when Hitler came to power in 1933, the legal office had to be closed and Neumann had to flee from Germany. In London, he in 1936 obtained his second doctoral degree from the London School of Economics with the work "The Governance of the Rule of Law" under the supervision of Harold Laski and Karl Mannheim. Neumann moved to New York in 1936, where he became a member of the Institute of Social Research (also known as the "Frankfurt School") that was then in exile in the USA. In 1942, he started working for the Office of Strategic Service (OSS), where he together with Herbert Marcuse and Otto Kirchheimer analysed Nazi Germany. In 1942, Neumann published his main book is Behemoth: The Structure and Practice of National Socialism, 1933-1944 ( $2^{\text {nd }}$, updated edition published in 1944), one of the most profound analyses of Nazi Germany's political economy and ideology. Franz L. Neumann died in 1954 in a car accident. 


\section{Notes}

${ }^{1} \mathrm{~A}$ few lines referring to a German pamphlet on child [psychology] omitted - ed.

${ }^{2}$ C. G. Jung has forcefully pointed to the significance of Schiller's Letters for our problem. Psychologische Typen, (Zurich, 1921), pp. 97-192. For the quotations from Schiller's Letters, I have used as a basis J. Weiss's translation of 1845, and modified where necessary. (The Aesthetic Letters, Essays, and the Philosophical Letters of Schiller, Boston, 1845.)

${ }^{3}$ Fifth Letter (cf. Weiss, p. 16).

${ }^{4}$ Sixth Letter (cf. Weiss, p. 21).

${ }^{5}$ Op. cit. (cf. Weiss, p. 22).

${ }^{6}$ Op. cit. (cf. Weiss, p. 23).

${ }^{7}$ The connection between Schiller and Hegel-Marx is clearly seen by Heinrich Popitz, Der entfreindete Mensch. Zeitkritik und Geschichtsphilosophie des jungen Marx (Basel, 1953) esp. pp. 28-35.

${ }^{8}$ Sixth Letter (cf. Weiss, p. 22).

${ }^{9}$ That is expressed in the sentence, "But even the scanty fragmentary portion, which still binds single members to the whole, depends not upon forms that present themselves spontaneously [...] but is prescribed to them with scrupulous strictness by a formula to which the free discernment of each one is restricted." Ibid.

${ }^{10}$ E. M. Butler, The Tyranny of Greece over Germany (New York and Cambridge, 1935). Chapter $\mathrm{V}$ is on Schiller.

${ }^{11}$ Ed. by Hermann Nohl, Tübingen, 1907.

${ }^{12}$ Ibid., pp. 378-382. Cf. esp. Herbert Marcuse, Reason and Revolution, Hegel and the Rise of Social Theory (New York, 1941) pp. 34-35.

${ }^{13}$ Cf. Marcuse, ibid.

${ }^{14}$ Marcuse, op. cit., pp. 274-287, and Popitz, op. cit., who adds little to Marcuse's analysis, but is interesting in that he constantly confronts Hegel and Marx.

15 "Oekonomisch-philosophische Manuskripte" in Marx-Engels Gesamtausgabe, First Div., Vol. III, p. 89.

${ }^{16}$ Op. cit., p. 87.

${ }^{17}$ Ibid., p. 118.

${ }^{18}$ Cf. esp. the two articles by Erich Fromm, "Die Psychoanalytische Charakterologie und ihre Bedeutung für die Sozialpsychologie," and, "Die sozialpsychologische Bedeutung der Mutterrechtstheorie," in Zeitschrift für Sozialforschung, 1932, pp. 253-277, and 1934, pp. 196-227. Both articles were written prior to Fromm's revisionist period, but the former already points toward it.

${ }^{19}$ (London, 1930), p. 39. This sentence is in itself valid only for patriarchal society. Whether it holds true for matriarchal society may be left open here. According to J. J. Bachofen, matri- 
archal right is "natura verum, the father only jure civile," (Das Mutterfecht, ed. by K. Meuli, Vol. I, p. 102); the stage of matriarchal right is that of poetry (pp. 124_5), Cf. also Fromm's article cited above.

${ }^{20}$ Freud, Civilization and its Discontents, p. 43.

${ }^{21}$ Ibid., p. 63

${ }^{22}$ Ibid., 63-4.

${ }^{23}$ Ibid., p. 80.

${ }^{24}$ For the systematic connection between sexuality and society in Freud (and in other theories) cf. Roger Bastide, Sociologie et Psychoanalyse (Paris, 1950) pp. $211 \mathrm{ff}$.

${ }^{25}$ The most important recent works are probably the following: K. Abraham, "A short study of the development of the libido, viewed in the light of mental disorders," in Selected Papers on Psycho-Analysis (Hogarth Press, London); Ernest Jones, "Fear, Guilt, Hate," in Papers on Psycho-Analysis (London, 1929, 5th ed.); Ernest Jones, "The Pathology of Morbid Anxiety," (1911) in Papers on Psycho-Analysis (4th ed.); Melanie Klein. "On the Theory of Anxiety and Guilt," in Developments in Psycho-Analysis (The International Psycho-Analytic Library; No. 43, London, 1952), pp. 271-291; Paula Heimann, "Notes on the Theory of Life and Death Instincts," in Developments in Psycho-Analysis, pp. 321-337. The following works of Freud: Civilization and its Discontents (London, 1920); Beyond the Pleasure Principle (London, 1922); The Ego and the Id (London, 1927); The Problem of Anxiety (New York, 1936).

${ }^{26}$ The Ego and the Id, pp. 84-5.

${ }^{27}[\mathrm{In}]$ The Problem of Anxiety.

${ }^{28}$ ErnestJones, "The Pathology of Morbid Anxiety."

${ }^{29}$ Cf. Freud's critique in Chapter $\mathrm{X}$ of The Problem of Anxiety.

${ }^{30}$ Cf. Paula Heimann's survey, "Notes on the Theory of Life and Death Instincts."

${ }^{31}$ For Freud-who follows Rank in this respect-when a danger situation appears which resembles birth. Cf. The Problem of Anxiety, Chapter XI.

${ }^{32}$ Sören Kierkegaard, The Concept of Dread (tr. Walter Lowrie, Princeton, 1944), p. 38, distinguishes fear and anxiety. Fear is the reaction against a concrete, external danger, while anxiety (the "dread" of the title) is a condition of being anxious.

${ }^{33}$ Cf. also Melanie Klein, "On the Theory of Anxiety and Guilt," loc. cit. p. 275.

${ }^{34} \mathrm{Cf}$. Freud in The Ego and the Id. The best formulation is in Franz Alexander, The Psychoanalysis of the Total Personality (New York, 1949), p. 101.

K. Abraham, "A short study of the development of the libido," op. cit., was probably the first to point out the connection between cannibalism on the one hand and guilt on the other.

${ }^{35}$ Melanie Klein, op. cit., p. 282. See also R. E. Money-Kyrle, Psychoanalysis and Politics (New York, n.d.).

${ }^{36}$ But cf. Franz Alexander, Psychoanalysis of the Total Personality, concerning the two main types of pathogenic educational methods: the excessively soft and indulgent and the excessively severe, loveless, Cf. Freud, Civilization and its Discontents, pp.115, 117. 
${ }^{37}$ There is agreement on this point. Cf. Freud, The Problem of Anxiety, Chapters IX and XI, B,; Melanie Klein, op. cit., p. 279, and many others.

${ }^{38}$ This is evidently what Freud has mind in The Ego and the Id, pp.71-72; and Melanie Klein, op. cit., p. 279.

${ }^{39}$ However, this is not completely correct, as Freud has pointed out: Group Psychology and the Analysis of the Ego (London, 1922) p. 1. After all, individual psychology can never do without relations to others (or at least one other person). The only exception is narcissism. But it does seem useful to retain the prevalent distinction of individual and social (or group) psychology.

${ }^{40}$ A useful compilation is in Paul Reiwald, Vom Geist der Massen. Handbuch der Massenpsychologie (Zurich, 1946).

${ }^{41}$ The most important book: La Foule Criminelle (Paris, 1898, 2d ed). Cf. Walter Moede, "Die Massen und Sozialpsychologie im kritischen Ueberblick," in Zeitschrift für paēdogogische Psychologie und experimentelle Paedogogik, 1915, Vol. XVI.

${ }^{42}$ Gustave Le Bon, The Crowd (London, 1896). A concrete application of his theory is in La Révolution Française et la Psychologie des Révolutions (Paris, 1912).

${ }^{43}$ The Crowd, p. 36. However, Le Bon admits (ibid., p. 37) that the masses can have a moralizing effect on the individual.

${ }^{44}$ Group Psychology and the Analysis of the Ego.

${ }^{45}$ Against this also Walter Lippmann, Public Opinion (New York, 1922), p. 197.

${ }^{46}$ Thus Freud, op. cit., pp. $21-22$.

${ }^{47}$ This also holds true for William MacDougall, The Group Mind (Cambridge, 1920) and for his theory of "primary induction of affects," for this too is at bottom nothing but imitation or suggestion. The positive element in MacDougall's theory will be worked out later.

${ }^{48}$ Group Psychology and the Analysis of the Ego, p. 38.

${ }^{49}$ Ibid., p. 120.

${ }^{50}$ Ibid., p. 91.

${ }^{51}$ Ibid., p. 65.

${ }^{52}$ Ranyard West, Conscience and Society. A Study of the Psychological Prerequisites of Law and Order (New York, 1945) p. 227.

${ }^{53}$ In the postscript (XII) to Group Psychology and the Analysis of the Ego, Freud formulates it a little differently. In the relation soldier-superior he assumes ego-idealization, in the relation of comrade to comrade he assumes ego-identification. The former may or may not be true. It may well be that the soldier does not identify himself in any way with the army or with his superior, or he may undertake ego-idealization with the superior or identify himself rationally with the army as such. The "ego-community" (co-operative identification, as I have called it) is in my opinion correctly described.

As far as the identification with a church is concerned, one must again make distinctions. Frequently, especially in Latin countries, the identification is strongly rationalist; in Germanic countries, above all under the influence of Catholic Romanticism, it is strongly libidinal. General statements may, perhaps, be made, but this does not seem to me possible at this time. 
${ }^{54}$ In political theory, Rousseau's volonté générale would correspond to this.

${ }^{55}$ Therefore R. Osborn's thesis is completely mistaken. In his attempt to integrate Marxism and Psychoanalysis (Freud and Marx [London, 1937]), he demands that leadership be crystallized in the form of a leader, and that we must idealize some individual for the masses on whom they can lean, whom they can love and obey.

${ }^{56}$ I use here, in place of many sources, Paul Piur, Cola di Rienzo (Vienna, 1931); Mario Emilio Cosenzo, Francesco Petrarca and the Revolution of Cola di Rienzo (Chicago, 1913); Max Horkheimer, "Egoismus und Freiheitsbewegung," in Zeitschrift für Sozialforschung, V (1936), pp. 161-231, is the most important analysis.

My essay on The Theory of Dictatorship, which is now in preparation, contains a detailed discussion; also anșnalysis of other caesarist movềsès. (See the incomplete version, printed in this volume-ed.)

There were many such movements at the end of the Middle Ages. An excellent survey is contained in G. Franz, Die agrarischen Unruhen des ausgehenden Mittelalters (Marburg, 1930).

${ }^{57}$ Var. XVVIII, Hortatoria, cited after Cosenzo, op. cit., pp. 16-44.

${ }^{58}$ Freud, Group Psychology and the Analysis of the Ego, p. 89.

${ }^{59}$ Le Tigre de 1560. Fascimile edition by Charles Read (Paris, 1875).

${ }^{60}$ Institutio Christianae Religionis, IV, cap. XX, 30 and summarized in the last of the 100 aphorisms.

${ }^{61}$ In addition to the well-known theory of resistance of Calvin, which is developed by Hotman in his Francogallia and Junis Brutus in his Vindiciae.

${ }^{62}$ The most important ones for France are those of the Parissan preacher Jean Boucher: De Justa Henrici Tertii Abdicatione, etc. (Paris,1589), and Sermons de la Simulée Conversion et Nullité de la Prétendue Absolution de Henry de Bourbon (Paris, 1594).

The pseudo-democratic character of these and similar Leaguist theories is discussed by M. Ch. Labitte, De la démocratie chez les Prédicateurs de la Ligue (Paris, 1841); on Boucher, pp. 193 seq.

${ }^{63}$ In his La Responsẻ de Jean Bodin à M. de Malestroit (1568). New edition by Henri Hauser (Paris, 1932) in the series: "La Vie Chère au XVlème Siècle."

${ }^{64}$ Cf. his Das Heptaplomeres des Jean Bodin (tr. by Guhrauer, Berlin, 1841).

${ }^{65}$ Les Six Livres de la République, Book I, chap. II and IV; Book VI, chap. IV.

${ }^{66}$ Op. cit., Book I, chap. I.

${ }^{67}$ Edited by E. Arbor (Westminster, 1895), pp. 3-4.

${ }^{68}$ In the Appendix of the Arbor edition.

${ }^{69}$ The literature is immense, Bernhard Duhr, S. J., Hundert Jesuitenfabeln (Freiburg i. B.) compiles the "fables-but proves too much. The Secret Policy of the English Society of Jesus (London,1715) is a good English example; Kaspar Schoppe, Arcana Societatis lesu Publico bono vulgata cum appendicibus utillissimus Geneva (?), 1635) a German one; A Startling Disclosure of the Secret Workings of the Jesuits, by a former French Roman Catholic, pub- 
lished by the author 1854, a French one. Rene Fueloep-Miller, Macht und Geheimnis des Jesuiten (Leipzig, 1929) is the best-known German general survey.

${ }^{70}$ On this cf. G. Monod in Academie dés Sciences, Morales et Politiques, Séances et Travaux, Vol. 1910, pp. 211-29.

${ }^{71}$ Gaston Martin, La franco-maçonnerie française et la Préparation de la revolution (Paris, 1926, 2d ed.) L. R. Gottschalk, "French Revolution-Conspiracy or Circumstance," in Persecution and Liberty, Essays in Honor of G. L. Burr (New York, 1921) pp. 445-472.

${ }^{72}$ Details in Eugen Lennhoff, Politische Geheimbünde (Zurich, 1931) pp. $17 \mathrm{ff}$.

${ }^{73}$ Friedrich Wichtel's well-known book, Weltfreimaurerei, Weltrevolution, Weltrepublik (1919) traces all distress after 1917-18 back to freemasons. Cf. Eugen Lennhoff, Die Freimaurer (Zürich,1929), p. 412.

${ }^{74}$ Curzio Malaparte, Die Technik des Staatsstreichs (Berlin 1932) is the best-known example

${ }^{75}$ On this point cf. the cautious analysis by Donald Greer, The Incidence of the Terror during the French Revolution (Cambridge, U.S., 1935).

${ }^{76}$ The following editions: German: Z. Gottfried Beck (Pseud. Ludwig Mueller von Hausen), "Die Geheimnisse der Weisen von Zion," Charlottenburg, 1919). This edition was acquired by the NSDAP in 1929. French: Mgr. E. Jouin, Le péril judéo-maçonnique, Vol. IV. (Paris, 1920). English: V. E. Marsden (trans.), The Protocols of the Learned Elders of Zion (London, 1921). American: The Protocols and World Revolution (Boston, 1920) and many others. The excellent book by John S. Curtiss, An Appraisal of the Protocols of Zion (New York, 1942) contains the best account of the history of this famous forgery. The work of Curtiss was written under the auspices of thirteen of the most notable American historians.

${ }^{77}$ Cf. E. Raas and F. Brunschvig, Vernichtung einer Fälschung: der Prozess um die erfundenen Weisen von Zion (Zurich, 1938).

${ }^{78}$ First ed., 1864. New ed., (Paris, 1948).

${ }^{79}$ The reasons which made National Socialism adopt the Protocols are detailed by Hitler himself. Mein Kampf, pp. 423 ff.

${ }^{80}$ In my Behemoth: The Structure and Practice of National Socialism (New York, 1942; 2d ed., 1944), p. 121.

${ }^{81}$ Cf. Jacques Maritain, Anti-Semitism (London, 1939), p. 27.

${ }^{82}$ For details cf. my book, op. cit., pp. 120-29, and the appendix to this chapter in the second edition (New York, 1944).

${ }^{83}$ The connection between anxiety and antisemitism has been empirically verified by Bruno Bettelheim and Morris Janowitz, Dynamics of Prejudice. A Psychological and Sociological Study of Veterans (New York, 1950), chap. VI.

${ }^{84}$ Carl Schmitt saw this correctly, Der Begriff des Politiscfien, but made a general theory of it instead of limiting it to regressive mass movements.

${ }^{85}$ This point is also illuminated by the Bettelheim-Janowitz study. 
${ }^{86}$ Harold D. Lasswell, "The Psychology of Hitlerism," in The Political Quarterly (1933), pp. 373-384; also in The Analysis of Political Behavior (New York, 1. 235-245. Quotation on p. 236.

${ }^{87}$ In my essay, "The Theory of Dictatorship." (See the incomplete version printed in this volume-ed.)

${ }^{88}$ Cf. my essay, "Social Structure and National Socialism" (unpublished).

${ }^{89}$ The Neurotic Personality of Our Time (New York, 1937) chs. XI and XII.

${ }^{90}$ Theory of Moral Sentiments (2 vols., 1790) Vol. I, Part III, chap. III, p. 339.

${ }^{91}$ Ibid., Vol. I, Part II, Sect. II, chap. II, p. 206; on the juristic problem, see Franz Boehm, Wettberwerb und Monopolkampf (Berlin, 1933).

${ }^{92}$ Erich Fromm who, in Man for Himself (New York,1947) pp. 67-81, regards the market operation (i.e., exchange) as depersonalizing and empty, and claims that it leads to rising discontent, seems to overlook this. Fromm's more correct thesis (in Escape from Freedom, New York, 1941) that the loss of the ego results from the discrepancy between the ideology of free competition and the actual monopolization of power, can also not be fully accepted. Against this, correctly: Theodor W. Adorno, "Zum Verhältnis von Psychoanalyse und Gesellschaftstheorie," in Psyche, VI, 1952-3, p. 10.

${ }^{93}$ In a study now in the process of completion, on "Concept of Virtue in Politics," I attempt to bring this proof. (This study was not completed-ed.)

${ }^{94}$ To this claim corresponds in the social sphere the petty bourgeois socialism, say of a Proudhon, to whom the distress of society seems to stem from exchange, not from the process of production.

${ }^{95}$ Now in France, too: Charles Henri Sévène, L'abstentionisme politique en France (Paris, n.d., 1953?).

${ }^{96}$ On this cf. my introduction to Montesquieu, The Spirit of the Laws (New York, 1949), reprinted in this volume.

${ }^{97}$ One has to be clear about the fact that a totally repressive system is held together not by neurotic anxiety alone-it depends on keeping this anxiety alive in significant groups-but that material advantages and prestige are equally important.

${ }^{98}$ Book IV, ch. 83 (tr. Crawley, New York, 1934).

${ }^{99}$ Modern research, synthesized by H. Mitchell, Sparta (Cambridge, England, 1952) pp. 16266 , accepts the reports of Thucydides and Plutarch.

${ }^{100}$ Lycurgus (tr. Dryden, revised by A. H. Clough).

${ }^{101}$ Preston H. Epps, "Fear in Spartan Character," in Classical Philology, January 1933, pp. $12-30$, proves, successfully in my view, that anxiety was the constitutive element of the Spartan character. Cf. Plutarch, Cleomenes, 9, and Lysander, 30.5; Herodotus, VI, 79-80.

${ }^{102}$ Part II, ch. 6, p. 393 (tr. Constance Garnett, New York,1936).

${ }^{103}$ Civilization and its Discontents, p. 118.

${ }^{104}$ The Ego and the Id., p. 77. 
${ }^{105}$ In Kierkegaard, (op. cit., pp. 65, 67) we find the following formulations- naturally from different theoretical presuppositions:

1. The individual produces in in his dread of sin.

2. The individual in dread (not of becoming guilty but) of being thought guilty becomes guilty.

${ }^{106}$ The significance of the superego for Freud's theory is not quite clear to me. If it means the "social conscience," that is, the sum of moral convictions that prevail is a society, one gets into difficulties when antagonistic convictions confront each other. But if it is the individual, unconscious feeling of guilt, then social norms could play no part.

In our example it is indifferent which interpretation of the superego should be accepted. According to the former: the prevalent moral convictions of Germany, even under National Socialism, proscribed murder. The orders of superiors to gas Jews because that would be useful to Germany collided with the prevailing morality. This is shown by the fact that these murders had to be committed in secret.

According to the latter interpretation: since the SS murderers had their childhood experiences under the old morality, they must have had at least an unconscious feeling of guilt.

${ }^{107}$ In his article "The Covenant of the Gangsters" in The Journal of Criminal Psychopathology, Vol. IV, No. 3 (1943), pp. 445-58, Ernst Kris develops a similar thesis which he, however, does not limit to the immediate participants in the crime but extends to the whole German people. That the National Socialists made the attempt to make the whole people into accomplices is, of course, beyond doubt. It can hardly be claimed that they succeeded.

${ }^{108}$ Ed. Weiss, p. 29.

${ }^{109}$ Ibid., p. 35.

${ }^{110}$ Freud, Civilization and its Discontents, p. 38. 